\title{
UK scientists welcome changes to controversial research reforms
}

Amendments aim to protect autonomy and the independence of research funders from political interference.

Inga Vesper

28 February 2017 | Corrected: 03 March 2017

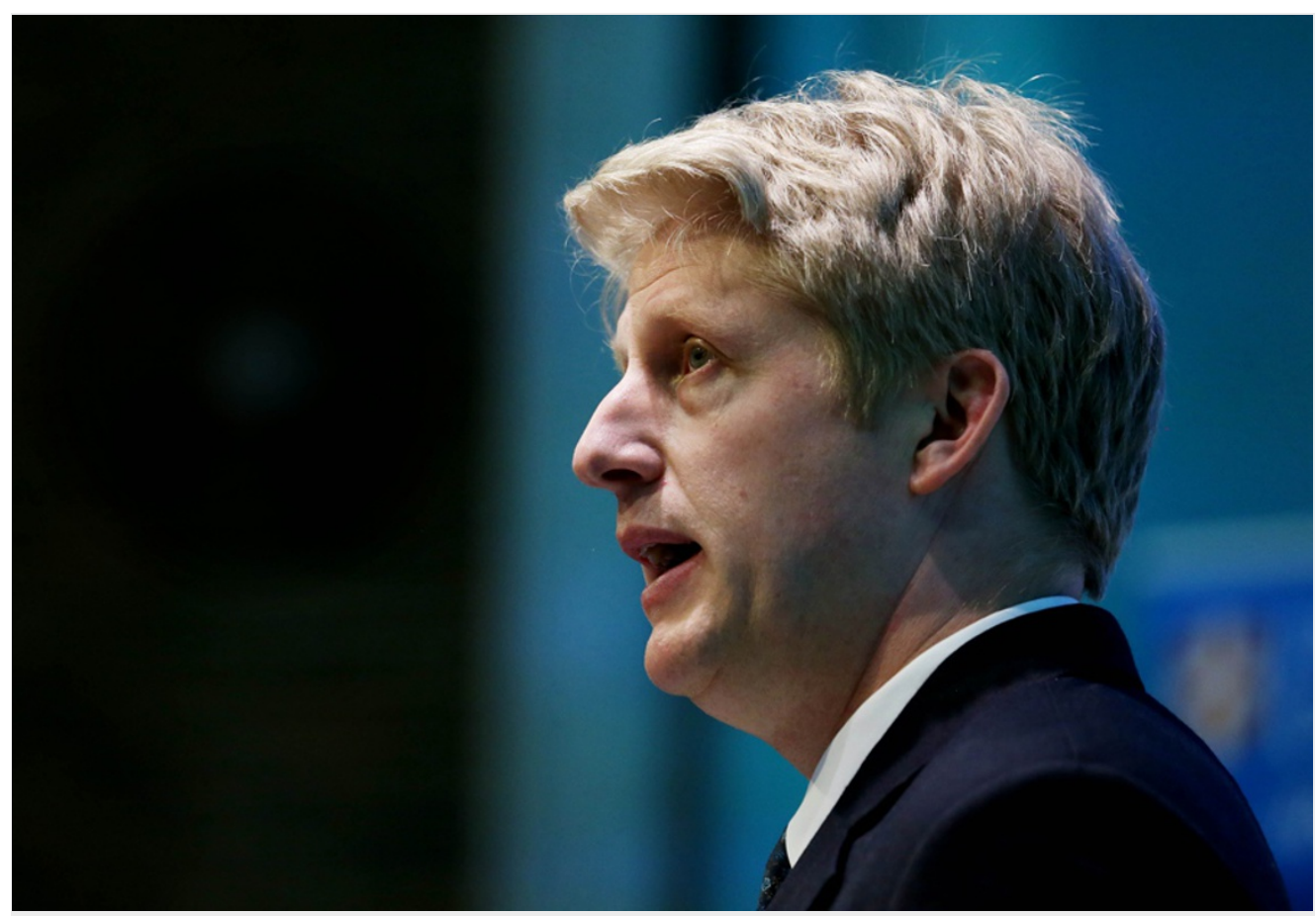

Chris Radbum/PA Archive/PA Images

Science minister Jo Johnson has proposed writing into law a long-held principle that politicians should not interfere directly in research-funding decisions.

UK scientists who had vigorously protested against a planned shake-up of the way their country's research is funded say they're largely reassured after the government announced amendments to the plans.

Science minister Jo Johnson announced a package of changes last week that look likely to smooth the way for the reforms to become law - although not everyone is satisfied.

The proposed reforms would bring the country's separate research councils together under a single, central funder, called United Kingdom Research and Innovation (UKRI), and would create a government body to regulate what UK universities teach. The latest changes are designed to soothe fears of excessive government control over what gets funded and taught in British universities, policy experts say.

Most unusually, Johnson has suggested writing into law a long-held principle in UK science funding, termed the Haldane principle that research-funding decisions should be protected from political interference. "Decisions on individual research proposals are best taken following an evaluation of the quality and likely impact of the proposals (e.g. a peer review process)," the revised law notes.

"We applaud the government's intention to recognize that those best able to decide what should be funded are not always politicians," says Naomi Weir, deputy director of the London-based Campaign for Science and Engineering. "It is such a difficult thing to put in legislation, and it's good that the government is trying to do that."

Among other amendments, the changes include promises to maintain the autonomy of universities and, according to government documents, "specify the freedoms of academic staff to question and test received wisdom, and to put forward new ideas and controversial or unpopular opinions".

The changes show that the government has listened to scientists before "tinkering further" with the UK research-funding system, says 
James Wilsdon, who studies research policy at the University of Sheffield, UK, and who also chairs a lobby group, Campaign for Social Science. "This is a serious and substantial package of amendments that should go a long way to assuaging any lingering concerns," he adds.

\section{Point of principle}

Many policy experts note that the government has not been quick to make amendments to its proposals. Criticisms were first heard in October 2016. The draft legislation passed easily through the country's lower chamber of Parliament, the House of Commons, but has encountered fiercer resistance this year in the upper chamber, the House of Lords, many members of which have a science or education background.

"I am pleased with the amendments," says John Krebs, a member of the House of Lords and a zoologist at the University of Oxford, UK, who last year had warned against adopting the reforms. He says that incorporating the Haldane principle is "a significant and welcome concession", and that he is reassured by other amendments designed to protect the research councils' autonomy and to make sure that the allocation of research funding to the various councils remains transparent.

But another House of Lords scientist, Martin Rees — an astrophysicist at the University of Cambridge, UK, who has criticized the idea of creating UKRI - says he still worries that the new body will have too much power over what gets funded.

The law will see its next hearing in the House of Lords on 6 March — and further changes might be suggested at that stage. After that, any changes have to be agreed again by the House of Commons. But the mood among UK universities is that the reforms will now go through, says Andy Westwood, a policy expert at the University of Wolverhampton, UK.

Ironically, says Westwood, the writing into law of the Haldane principle could end up serving the government more than it does researchers, because it hammers out an agreed meaning for what has until now been a vague principle of independence that could be called upon whenever researchers felt threatened by government interference.

"Haldane was probably more powerful when it was not enshrined, because academics could always shape it to fit their argument," Westwood says.

Nature | doi:10.1038/nature.2017.21571

\section{Corrections}

Corrected:An earlier version of this story gave an incorrect affiliation for Andy Westwood. 